\title{
Cloning and Expression of Helicobacter pylori ulcer Associated Gene - iceA1 in Brinjal (Solanum melongena L.)
}

\author{
Mohammad Javad Mehran', Basaralu Yadurappa Sathish Kumar 1,2, ${ }^{,}$Nanjundappa Haraprasad ${ }^{3}$, Rambod Barzigar ${ }^{1}$, Bashasab Fakrudin ${ }^{4}$, \\ Sayan Paul5,6 \\ 1JSS Research Foundation, SJCE Technical Campus, Mysore, Karnataka, INDIA \\ 2Department of Biotechnology, JSS College, Ooty Road, Mysore, Karnataka, INDIA. \\ 3JSS Science and Technology University, SJCE, Technical Campus, Mysore, Karnataka, INDIA. \\ ${ }^{4}$ Department of Biotechnology and Crop Improvement, College of Horticulture, University of Horticulture Sciences Campus, GKVK Post, Bengaluru, Karnataka, INDIA. \\ Department of Biotechnology, Manonmaniam Sundaranar University, Tirunelveli, Tamilnadu, INDIA. \\ ${ }^{6}$ Centre for Cardiovascular Biology and Disease, Institute for Stem Cell Science and Regenerative Medicine (inStem), Bangalore, INDIA
}

\begin{abstract}
Background: Plant biotechnology revolutionized the branch of plant sciences contributing to improving crop production. Helicobacter pylori was predominantly seen among all the sectors of the human population, closely stuck to stomach ulcers and cancer. Even though traditional vaccines are effective in preventing $H$. pylori, edible and non-edible parts of special transgenic plants were also being generated to express its antigens which could elicit an immune response after consuming. The induce by contact with epithelium (iceA1) protein of $H$. pylori is associated with virulence and stated as predisposing factor to stomach cancer. Objectives: This study intends to study the expression levels of iceA1 gene in the brinjal plant. Materials and Methods: The present study, magnified the iceA1 gene from H. pylori strain 26695 and transformed it into callus of brinjal (from leaf explants) through Agrobacterium tumefacians (EHA105). pBI121 vector was used to construct the plant expression vector, and the transgenic plants generated were further validated through gene amplification and protein expression studies. Results: Out of the 46 plants obtained from this study, five of them were found to be positive for the iceA1 expression
\end{abstract}

as seen on validation assays like gene amplification and protein expression studies. Conclusion: The study could beneficially produce a vaccine candidate against $H$. pylori from transgenic brinjal. In Addition, it could provide, valid scientific data which can further be used by researchers.

Key words: Helicobacter pylori, Transgenic brinjal, iceA1, Agrobacterium, Edible Vaccine.

Correspondence

Dr. Basaralu Yadurappa Sathish Kumar, ${ }^{1,2}$

'JSS Research Foundation, SJCE Technical Campus, Mysore-570006, Karnataka, INDIA.

${ }^{2}$ Postgraduate Department of Biotechnology, JSS College, Mysore-570025, Karnataka, INDIA.

Email id: bysathish@gmail.com;

ORCID: 0000-0003-0085-1246

DOI: 10.5530/ijpi.2021.3.60

\section{INTRODUCTION}

Since its inception, plant biotechnology has always worked towards improving crop production and significantly leading to sustainability in the agriculture sector. ${ }^{1}$ Vaccines, on the other hand, try to generate immune response, towards inactivated biological samples from bacteria or viruses forming a paramount revolution in the $19^{\text {th }}$ century. To define, they are simply proteins, which bear resemblance to a pathogen, in an inactivated form stimulating the body's immune system in recognizing the foreign antigen at a later stage. ${ }^{2}$

A new form of vaccine has been shaped in the recent decades, to minimize the risk effects of earlier mentioned traditional vaccines. Such vaccines are mass-produced from genetically modified plants, which are artificially inserted with a disease-causing gene of pathogens (bacteria or virus), without altering the immunogenic capacity. These vaccines, called edible vaccines are found to switch on both systemic and mucosal response against a disease-causing pathogen. ${ }^{2}$ The ever-increasing world's population along with living standards are forcing the biologists to implement novel agro-biotechnological methods wherein they can substantially generate crops. ${ }^{3}$ that are of high yield producing diverse rich products like antibodies, therapeutic proteins, vaccines and many more secondary metabolites. ${ }^{4}$ Gastric cancer is the $7^{\text {th }}$ most prevalent cancer which accounts for $8.3 \%$ of global cancer mortality. ${ }^{5}$
This pathogenesis is due to the interaction of Helicobacter pylori with the environment and genetic factors. The pathogen invades, survives, colonizes and stimulates inflammation along the stomach mucosal layer causing severe evasion eventually leading to malignancy. ${ }^{6}$ Helicobacter pylori, a flagellated, helical-shaped bacterium, is said to enhance its survival within the gastric environment. Such spiral form makes it capable to pierce through the gastric layer, colonizing the epithelium leading to aggressive invasiveness. ${ }^{6}$

H. pylori, was credited as class I carcinogen causing gastric cancer, by both the World Health Organization (WHO) and the International Agency for Research on Cancer. ${ }^{7}$ Its infection among the human hosts leads to chronic gastritis causing peptic ulcer disease. ${ }^{8}$ It also plays a critical role in the development of gastric adenocarcinoma mostly associated with stomach mucosa-associated lymphoid tissue (MALT) lymphoma, thereby adding to stomach carcinogenesis elevating the gastric cells to proliferate profoundly. ${ }^{9}$

Such infections are estimated to be $85-95 \%$ among the developing nations and accurately $30-50 \%$ within developed nations. ${ }^{10}$ Bacteria enter the host either by oral-to-oral or fecal-to-oral routes. H. pylori adapts itself, within the gastric microenvironment, enabling it to survive even at low $\mathrm{pH}$ of $3.0 .{ }^{11} \mathrm{H}$. pylori is said to enhance its virulence, by altering the host signaling pathways creating an inflammatory response

This is an open access article distributed under the terms of the Creative Commons Attribution-NonCommercial-ShareAlike 4.0 License, which allows others to remix, tweak, and build upon the work non-commercially, as long as the author is credited and the new creations are licensed under the identical terms. 
within the stomach mucosal layer. This causes the epigenetic outcomes within the stomach cells leading to gastric invasion and gastritis. ${ }^{12}$ With increasing antibiotic resistance, the pathogen is prevailing and predominating causing acute to chronic gastritis which further leads to peptic ulcers and then gastric cancer. ${ }^{13}$

Many virulence factors are said to influence the pathogenesis of the bacteria along with the iceA (induce by contact with epithelium) gene. This gene attaches to the stomach epithelial layer invading the gastric mucosa. This is said to contain two forms (iceA1 and iceA2) whose role in virulence, ${ }^{14}$ is still controversial and unclear. ${ }^{15}$ This ice $A 1$ form is stated to be connected with peptic ulcer disease, ${ }^{16}$ and also being considered as a marker for peptic ulcer disease. ${ }^{17}$ The bacteria transcribes this iceA1 gene which aids in adhering to the epithelial cells, proposing its role in virulence, ${ }^{18}$ Cheng et al., 2007, were successful in generating plant expression vectors loaded with Helicobacter proteins like cagA and ureB which could express the fusion proteins against the strains. ${ }^{19}$

Traditional vaccine production though in need and urgency still is stalled due to the production cost and purification methods. ${ }^{20}$ Moreover, plant pathogens and many secondary metabolites do interfere with the overall purification at an industrial level. ${ }^{21}$ In recent decades, the plant expression vectors were considered and being studies to deliver recombinant proteins into the host in the name of vaccine antigens. ${ }^{22}$ Such plant-derived therapeutic proteins are cost-effective in production with high quality. In addition, they are free from animal pathogens eligible for mass production. ${ }^{23}$

Gene expression studies, by blotting and real-time PCR methodologies, are predominating in recent years owing to their robustness and specificity. ${ }^{24,25}$ Moreover, these methodologies are overlaid the microarray assays, with respect to expression levels. ${ }^{26,27}$ Plant expression systems make the production of edible vaccines very easy from leaves, fruits and vegetables. Such oral-based delivery systems will definitely bypass the side effects of sterile administration methods of traditional vaccines. In addition, the purification process and old storage could be avoided which is unavoidable with the conventional vaccines. ${ }^{28}$

Brinjal, popularly called eggplant, is considered a common man's vegetable in India. ${ }^{29}$ It is crowned as a common man's vegetable owing to its popularity in usage within the country. ${ }^{30} \mathrm{It}$ is also crowned as the "King of Vegetables' in regard to its immense medicinal and pharmaceutical products. ${ }^{31}$ It is seen commonly among the dishes of every household in India irrespective of their food preferences and income levels. It is having less calorific value with high nutritional benefits and water content. In addition, it is rich in fiber and minerals like calcium, phosphorus, folate. It also contains ample amounts of vitamin B and C. ${ }^{32}$ Brinjal was now deeply buried into the Indian culture with numerous folk songs being tuned and played on the king which is humble among other vegetables. ${ }^{33}$ To trace the significant application of plants to produce $H$. pylori iceA1, this study expressed the clone of the iceA1 gene from $H$. pylori strain 26695 in the brinjal plant, Solanum melongena L. Cultivar Arka Keshav. We have exemplified the expression of the iceA1 gene in brinjal plants, which could elicit an immune response against $H$. pylori strains. The results could pave paths to bring in possible vaccine candidates against H. pylori from the brinjal plant.

\section{MATERIALS AND METHODS}

\section{Plant material and Experimentation}

Brinjal (Solanum melongena L.Cultivar Arka Keshav) commonly called eggplant was collected from the Division of Vegetable Crops, IIHR, Bangalore. The experimentation was conducted with prior approval from the Institutional Biosafety Committee (IBSC) of JSS College, Mysore at Postgraduate Department of Biotechnology, JSS College,
Mysuru, Genei India Pvt. Ltd., Bangalore and Department of Biotechnology and Crop Improvement, College of Horticulture, University of Horticulture Sciences, GKVK Post, Bangalore. Appropriate permission for the collection of plant or seed specimens has been obtained from the College of Horticulture, University of Horticulture Sciences, GKVK Post, Bangalore. The study was conducted in accordance with relevant international guidelines and legislation and all the experimental plants are discarded immediately after experimentation and before flowering as per the procedure.

\section{Chemicals}

Genomic DNA from Helicobacter pylori 26695 was bought from (ATCC ${ }^{\circledR}$ $\left.700392 \mathrm{DQ}^{\mathrm{m}}\right)$ ATCC. All the chemicals used in the study were bought from Sigma Chemical Co and HiMedia and were of molecular grade and primers were ordered from Sigma Ltd, Bangalore. DNA ladders, SacI and BamHI, T4 DNA ligase were all bought from Genei Laboratories, Bangalore.

E. coli (DH5a) (F', end A1 hsdR17 ( $\left.\mathrm{rk}^{-} \mathrm{mk}^{+}\right)$glnV44 thi-1 recAlgyrA (Nalr) relA1(lacZY, AargF) U169deo RФ 80dlac (lacZ) M15 and PBI121 with T7 promoter was obtained from Genei Laboratories Pvt Ltd and Invitrogen Life Technologies, USA respectively. Agrobacterium tumefaciens strain (EHA105) was a gift from Department of Biotechnology, IIHR, Bangalore. The plant material used in our study was a callus transformed with Agrobacterium tumefaciens (EHA105), with PBI121 vector carrying the iceA1 gene in the T-DNA [Figure 1].

Restriction sites of BamHI and SacI can be seen in the image. $35 \mathrm{~S}$ is the promoter and $35 \mathrm{~S}$ polyA is the adenylation signal for the ice $A 1$ gene. LB: left border; RB: Right border.

\section{PCR amplification of iceA1 gene}

Gene amplification was done with iceA1 forward and reverse specific primers (Table 1 ) which were designed based on the $H$. pylori sequence corresponding to $\sim 519 \mathrm{bp}$. The reaction mixture consisted of approximately 50ng of total gDNA as template, Hotstart Taq DNA polymerase (1U), dNTPs $\left(0.2 \mathrm{mM}\right.$ each), $1 \times$ PCR buffer, $\mathrm{MgCl}_{2}(3 \mathrm{mM})$ and primers $(10 \mathrm{pmol}$ each) in a total reaction volume of $25 \mu \mathrm{l}$. PCR parameters were initial denaturation at $94^{\circ} \mathrm{C}$ for $2 \mathrm{~min}$ followed by 35 cycles $\left(94^{\circ} \mathrm{C}, 40 \mathrm{sec}\right.$; $56^{\circ} \mathrm{C} 45 \mathrm{sec} ; 72^{\circ} \mathrm{C} 1 \mathrm{~min}$ ) followed by a $15 \mathrm{~min}$ final extension at $72^{\circ} \mathrm{C}$. The PCR products were then resolved on $1.0 \%$ agarose gel and determined using a UV transilluminator. Genei clean purification system (Gel Extraction Kit, Genei) was used to purify the PCR products from the gel. Miniprep Kit (Genei) was used in isolating plasmid DNA with high yields $(35 \mu \mathrm{l})$ as instructed in the manual.

\section{Cloning of iceA1 gene into pBl121}

In order to achieve the transgenics which could induce an immune $r$ esponse among the patients of H.pylori, we cloned iceA 1 fragment (Partial) of $\sim 519 \mathrm{bp}$ into bacterial strains, which was then amplified and purified followed by digestion with $\mathrm{BamHI}$ and $\mathrm{SacI}\left(37^{\circ} \mathrm{C}\right.$ for $\left.2 \mathrm{hr}\right)$. The plasmid used was also digested with the same restriction enzymes and the bands

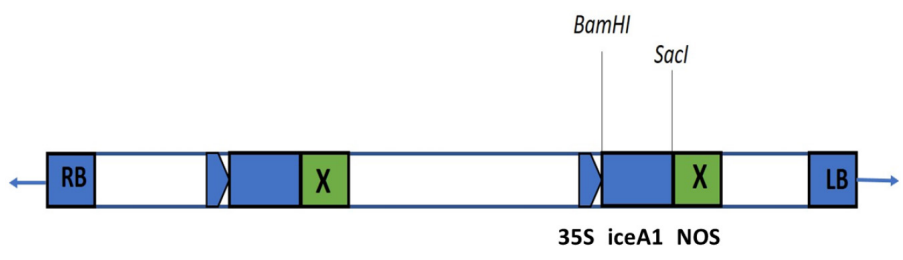

Figure 1: Schematic diagram of T-DNA of the pBI121 vector used in transforming brinjal callus through Agrobacterium tumefaciens. 
obtained were excised and cleaned using the Genei gel extraction kit. The digested vector and iceA1 product were then ligated (T4 DNA ligase) overnight at $16^{\circ} \mathrm{C}$ and then transformed into E.coli DH5a strain. Recombinant clones were screened and the digests were confirmed using the sequencing study (Eurofins, Bangalore).

\section{Preparation of competent cells and Transformation}

The $E$. coli cells were made competent by the calcium chloride method ${ }^{34}$ and spread and incubated on an LB-agar plate without antibiotic at $37^{\circ} \mathrm{C}$ for $12 \mathrm{hr}$. A single isolated colony was inoculated into $10 \mathrm{ml}$ of $\mathrm{LB}$ medium and grown till the optical density of $0.4-0.5$ at $660 \mathrm{~nm}(3-4 \mathrm{hr})$ was achieved. The cells were then chilled on ice for $30 \mathrm{~min}$ and harvested by centrifugation at $3000 \mathrm{rpm}$ in SS 34 rotor (Sorvall refrigerated centrifuge, Evolution RC) at about $4^{\circ} \mathrm{C}$ for $15 \mathrm{~min}$. The cell pellet obtained was then resuspended in a $30 \mathrm{ml}$ of filter-sterilized ice-cold acid salt buffer (100mM CaCl $2,70 \mathrm{mM} \mathrm{MnCl}_{2}$ and $40 \mathrm{mM}$ sodium acetate, $\mathrm{pH}(5.2-5.5)$ and incubated for $45 \mathrm{~min}$ on ice.

The cells were pelleted down at $3000 \mathrm{rpm}$ for $15 \mathrm{~min}$ at $4^{\circ} \mathrm{C}$ and the pellet obtained was resuspended in $1 / 25^{\text {th }}$ volume of culture in acid salt buffer containing $20 \%$ glycerol (cell pellet from $90 \mathrm{ml}$ culture was suspended in $4.5 \mathrm{ml}$ of buffer) and stored at $-70^{\circ} \mathrm{C}$ until further use as $50 \mu$ aliquots. The competent DH5a E. coli cells were transformed with PBI121 vector containing ice 11 gene by incubating them on ice for $30 \mathrm{~min}$ followed by heat shock treatment at $37^{\circ} \mathrm{C}$ for $5 \mathrm{~min}$. Following which the transformed cells were plated on LB agar plates containing antibiotics (Kanamycin $20 \mu \mathrm{g} / \mathrm{ml}$ ) and incubated at $37^{\circ} \mathrm{C}$. The bacterial colonies were further screened for PBI121 containing iceA1 inserts.

\section{Purification of the plasmid}

Single isolated colonies were inoculated into $5 \mathrm{ml}$ of $\mathrm{LB}$ broth (with Kanamycin $20 \mu \mathrm{g} / \mathrm{ml}$ ) and incubated at $37^{\circ} \mathrm{C}$ for $12 \mathrm{hr}$ on a shaker incubator (120rpm). The vector was isolated using the alkaline lysis method. ${ }^{35} \mathrm{In}$ brief, overnight culture was centrifuged at $6000 \mathrm{~g}$ for $5 \mathrm{~min}$ at $4^{\circ} \mathrm{C}$ and the pellet obtained was resuspended in $200 \mu$ l of prechilled solution I. $200 \mu \mathrm{l}$ of freshly prepared solution II was added to the tube and mixed gently by inverting upside down, followed by adding, $200 \mu$ of solution III. Contents are mixed gently and incubated on ice for $10 \mathrm{~min}$. Following incubation, the cell lysates were then centrifuged at $8000 \mathrm{~g}$ for $10 \mathrm{~min}$ at $4^{\circ} \mathrm{C}$. The phenol: chloroform: iso-amylalcohol mixture $(25: 24: 1 ; \mathrm{v} / \mathrm{v})$ was added to the supernatant and mixed thoroughly. The contents were then centrifuged at $8000 \mathrm{~g}$ for $10 \mathrm{~min}$ at $4^{\circ} \mathrm{C}$ and added with an equal volume of pre-chilled isopropanol to precipitate the DNA. The DNA was then pelleted at $8000 \mathrm{~g}$ for $10 \mathrm{~min}$ at $4^{\circ} \mathrm{C}$ and resuspended in $10 \mathrm{mM}$ TE buffer for further use. The plasmid purity was checked on $0.8 \%$ agarose gel electrophoresis and the positive clones were confirmed by restriction digestion followed by DNA sequencing.

\section{Callus induction}

Brinjal seeds (pre-treated with 250ppm of GA3; Gibberellic acid) of variety Arka Keshav, were surface sterilized with sodium hypochlorite (6\%) and water in a 1:1 ratio and rinsed with sterile distilled water for 3-4 times. About 20-25 seeds were then inoculated on Petri plates containing N6 callus induction medium (with 10,000mg/l Myoinositol, 200mg/l glycine, 50mg/l Thiamine $\mathrm{HCl}, 50 \mathrm{mg} / \mathrm{l}$ Pyridoxine $\mathrm{HCl}$, and $50 \mathrm{mg} / \mathrm{l}$ of Nicotinic acid) of $\mathrm{pH} 5.75 .10 \mu \mathrm{M}$ of BAP and $1 \mu \mathrm{M}$ NAA were added to the medium after autoclaving the previously mentioned contents. $0.8 \%$ agar was used in solidifying the medium. The plates were then incubated at $25 \pm 2{ }^{\circ} \mathrm{C}$ in dark. The calli obtained were removed from the germinating seeds and sub-cultured on a fresh callus induction medium. Median portions of cotyledonary leaves and transversely cut segments of hypocotyls were used as explants in the present study. ${ }^{36}$

\section{Callus transformation with Agrobacterium}

The calli obtained was transformed with Agrobacterium (EHA105) as per the protocol described by Patel et al., 2013, ${ }^{37}$ with slight modifications. The vectors were introduced into Agrobacterium through electroporaton. In brief, to about $50 \mu \mathrm{l}$ of cells, $5 \mu$ of plasmid DNA was added and mixed thouroughly. The contents were then transferred to a prechilled cuvette and electroporated. The Agrobacterium tumefaciens mobilized with vector inserts, were inoculated into $5 \mathrm{ml}$ of YEP (yeast-extract-mannitol medium; pH 7.0) medium (with 20mg/l Rifampicin and 50mg/l Kanamycin) and incubated at $28^{\circ} \mathrm{C}$ in a shaking incubator (200rpm) overnight. The overnight culture was transferred to $45 \mathrm{ml}$ of infection media (MS basal media with Thiamine $\mathrm{HCl}$ [1mg/l], Myoinositol [250mg/l], Casein hydrolysate [1.0g/l ], Proline [690mg/l], Glucose [30g/l] , 2,4-D [5.0mg/l ] and Acetosyringone $[200 \mu \mathrm{M}])$ of $\mathrm{pH} 5.2$ and incubated at $28^{\circ} \mathrm{C}$ in a shaker incubator (200rpm) for about $48 \mathrm{hr}$ until the $\mathrm{OD}_{600}$ reaches $0.5-0.6$. Colony PCR of Agrobacterium was done to confirm the insert iceA1.

The embryogenic calli obtained was then infected with Agrobacterium by heat shock at $42^{\circ} \mathrm{C}$ for $3 \mathrm{~min}$ followed by $12 \mathrm{~min}$ incubation at room temperature. The calli was then blotted on to Whatman papers to remove excess bacterial suspension and then co-cultivated on co-cultivation media (media (MS basal media with Myoinositol [690mg/l], Casein hydrolysate $[1.0 \mathrm{~g} / \mathrm{l}]$, Proline $[1 \mathrm{gm} / \mathrm{l}]$, maltose $[0.5 \mathrm{mg} / 1], 2,4-\mathrm{D}[0.1 \mathrm{mg} / \mathrm{l}]$, BAP $[0.1 \mathrm{mg} / \mathrm{l}]$ and Acetosyringone $[200 \mu \mathrm{M}]$, Phytagel $[3 \mathrm{gm} / \mathrm{l})$ of $\mathrm{pH} 5.8$ for 2 days in dark at $25^{\circ} \mathrm{C}$. After two days of cocultivation, the explants were transferred to the selection medium (media with $100 \mathrm{mg} / \mathrm{l}$ of kanamycin) and carefully maintained on the selection medium for about 20 days with repeated subculturing for every 6 days on to fresh selection medium. After 3-4 weeks of selection, the calli growing on kanamycin alone were transferred to regeneration media (MS media with 2.0mg/l BAP, 30g/l Maltose, 3.0g/l Phytagel, 200mg/l Timentin and $50 \mathrm{mg} / \mathrm{l}$ hygromycin) and then incubated in light at $25^{\circ} \mathrm{C}$ for about 3 weeks. The regenerating shoots were carefully excised and transferred to cocultivation media with kanamycin $(25 \mathrm{mg} / 1)$ and cefotaxime $(250 \mathrm{mg} / \mathrm{l})$. The proliferating shoots were then transferred onto rooting medium (half-strength MS medium with $250 \mathrm{mg} / \mathrm{l}$ cefotaxim along with IBA $5 \mu \mathrm{M})$ and selection medium without kanamycin. On successful rooting, the plantlets were then subcultured into new bottles with a rooting medium and allowed to grow for 15 more days.

The primary transgenics about $8-10 \mathrm{~cm}$ with the proper shoot and root were removed carefully and replanted into 6inch pots containing 50:50 peat-lite/sand in the greenhouse $\left(26 / 22^{\circ} \mathrm{C}, 16 \mathrm{hr}\right.$ light/ $8 \mathrm{hr}$ dark and high humidity). Once the plants were acclimatized, they were transferred to growth chambers $\left(28 / 24^{\circ} \mathrm{C}, 16 \mathrm{hr}\right.$ light/ $8 \mathrm{hr}$ dark $)$ and given care and nutrients as per the standard management practice.

\section{Isolation of total genomic DNA from leaves}

A total of 46 plants were regenerated and from them, only five of them were found to be transgenic in nature which was confirmed with blotting and amplification stuides. Genomic DNA was isolated from the leaves by the CTAB method as described by Li, $\mathrm{Z}$ et al., $2020 .^{38}$ In brief, about $100 \mathrm{mg}$ of leaf tissue was homogenized with $0.5 \mathrm{ml}$ of extraction buffer (2\% CTAB, $1.4 \mathrm{M} \mathrm{NaCl}, 20 \mathrm{mM}$ EDTA, $10 \mathrm{mM}$ Tris $\mathrm{HCl} ; \mathrm{pH} 8.0$ ) containing $10 \mu \mathrm{l}$ of beta-mercaptoethanol. The contents were mixed gently and incubated for $30-40 \mathrm{~min}$ at $65^{\circ} \mathrm{C}$ in a water bath, and added with equal volumes of chloroform: isoamyl alcohol (24:1) following incubation. The contents were then centrifuged at 5000rpm for $15 \mathrm{~min}$ at room temperature and added with $1 / 10^{\text {th }}$ volume of $5 \mathrm{M} \mathrm{NaCl}$ and 0.8 volumes of ice-cold isopropanol to precipitate the DNA. The DNA obtained was then pelleted at $8000 \mathrm{rpm}$ for $10 \mathrm{~min}$ and washed with $70 \%$ ethanol. Following washing, the pellet was resuspended in $100 \mu \mathrm{l}$ of TE 
buffer. $5 \mu$ of RNase $(10 \mathrm{mg} / \mathrm{ml})$ was added to the DNA and stored at $-20^{\circ}$ $\mathrm{C}$ following incubation at $37^{\circ} \mathrm{C}$ for $1 \mathrm{hr}$.

\section{Primer design}

Forward and Reverse primers used in our study (Table 1) were designed using the Primer 3 software (version 4.13) based on mRNA sequences deposited in GenBank. ${ }^{39}$ The specificities of the primers were crosschecked by alignments with the original GenBank sequences using the standard nucleotide-nucleotide BLAST (blastn; provided online by $\mathrm{NCBI}) .^{40}$

\section{Protein extraction}

The leaf samples (both transgenic and control) were ground with liquid $\mathrm{N}_{2}$ in a mortar and pestle. About $0.2 \mathrm{gm}$ of tissue powder is resuspended in $2 \mathrm{ml}$ cold acetone and vortexed thoroughly for $30 \mathrm{sec}^{41}$ The pellet obtained was washed with acetone and centrifuged at $10000 \mathrm{~g}$ for $3 \mathrm{~min}$ at $4^{\circ} \mathrm{C}$. It was transferred into a mortar and ground further to a fine powder with quartz sand and transferred into $2 \mathrm{ml}$ microfuge tubes and rinsed with ice-cold $10 \%$ TCA 3 to 4 times and added with cold $80 \%$ acetone. Following centrifugation, the pellet was used for extraction at room temperature.

The phenol extraction method was used in the study, ${ }^{41}$ but with a slight modification. In brief, about $0.1 \mathrm{gm}$ of previously prepared powder was resuspended in $0.8 \mathrm{ml}$ phenol (Tris-buffered, $\mathrm{pH} 8.0$ ) and $0.8 \mathrm{ml}$ of SDS buffer (sucrose 30\%, SDS 2\%, 0.1M Tris- $\mathrm{HCl}, \mathrm{pH} 8.0,5 \%$ 2-mercaptoethanol). The contents are mixed thoroughly for $30 \mathrm{sec}$ and centrifuged at $10000 \mathrm{~g}, 3 \mathrm{~min}$. The upper phenol phase was collected in fresh tubes, and added with 5volumes of cold methanol and ammonium acetate $(0.1 \mathrm{M})$ to precipitate the proteins. Proteins precipitated were then recovered by centrifuging at $10000 \mathrm{~g}$ for $5 \mathrm{~min}$ and washed twice with cold methanolic ammonium acetate and ice cold $80 \%$ acetone twice. The pellet thus obtained was dried and resuspended in 2-DE rehydration solution (8M urea, 4\% CHAPS, 2\% IPG buffer, 20mM dithiothreitol) and quantified (Genei, Bangalore) using bovine serum albumin as standard.

Soluble proteins extracted were separated on SDS- polyacrylamide gel electrophoresis $(4.75 \%$ stacking and $12 \%$ resolving gel with $12 \%$ glycerol) and transferred onto Nylon membrane (Genei, Bangalore). The final concentration of the resolving buffer (Tris- $\mathrm{HCl}, \mathrm{pH}$ 8.8) was modified to $0.75 \mathrm{M}$, than the usual $0.375 \mathrm{M}$. Protein samples were denatured at $95^{\circ} \mathrm{C}$ for $3 \mathrm{~min}$ and resolved under constant $200 \mathrm{~V}$ in a Bio-Rad mini-SDS PAGE gel apparatus.

\section{RESULTS}

\section{PCR amplification and cloning of iceA1 gene into pBI121}

Gene amplification with iceA1 primers showed positive amplification with amplicon at about 519bp. The bands confirm the iceAl gene amplification [Figure 2]. The purified vectors were run on agarose gel (1\%) and the digests were found to yield two products releasing the iceA1 gene product at approximately 519bp [Figure 3]. The nucleotide sequence [Figure 4] obtained was compared to GenBank sequences and found to have a "perfect" match (similarity, 95.98\%) with sequences of their corresponding gene iceA1 from GenBank (GenBank ${ }^{\oplus}$ accession no. LC420461) as performed using BLAST (version 2.7). This variation

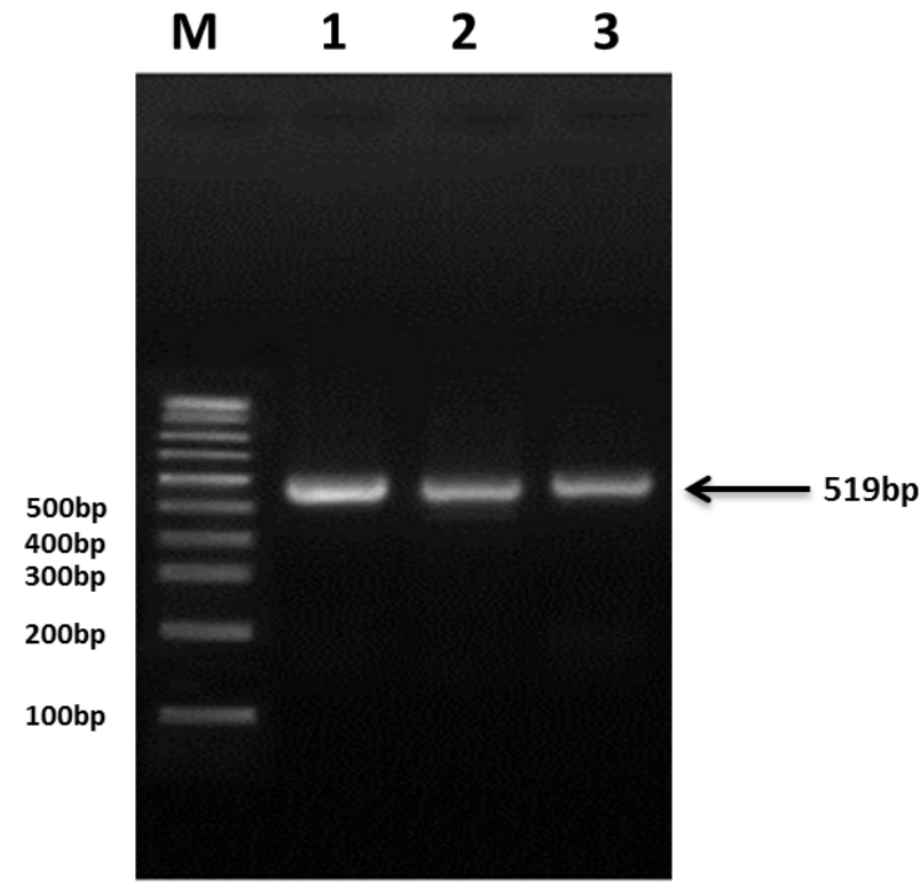

Figure 2: Image showing the iceA1 gene amplification separated on $1 \%$ agarose gel.

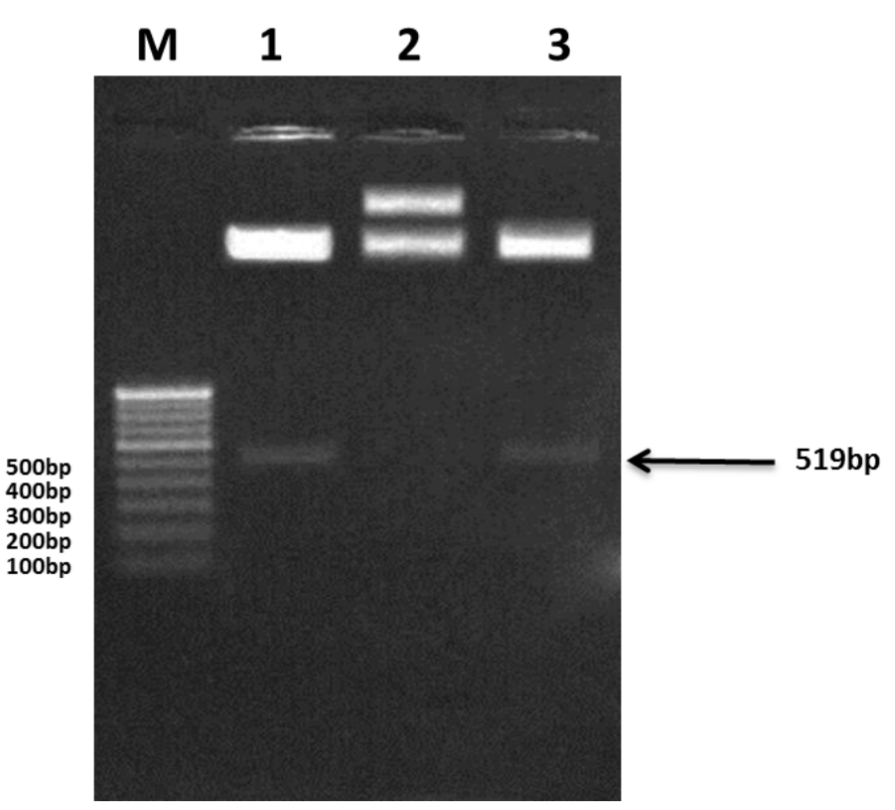

Figure 3: Restriction digestion of ligated pBI121-iceA1 using BamHI and SaCl on $1 \%$ agarose gel.

M Lane-100bp ladder was used as a ladder. Lane 1 and 3; pBI121- iceA 1 digest (with BamHl and Sacl) could be seen released iceA1 gene. Lane 2: pBI121-iceA1 (undigested); Image as viewed on Gel Dock.

Table 1: Table showing the list of primers used in the study. FP: Forward primer, RP: Reverse primer. Tm: melting temperature.

\begin{tabular}{ccccccc}
\hline Gene & & Sequence & Length & Tm & GC\% & Product length \\
\hline \multirow{2}{*}{$i c e A 1$} & FP & TATCTGGATCCATGGAGTTTGATAAAGGGCAAACTC & 36 & 76 & 41.7 & $519 \mathrm{bp}$ \\
& RP & ATATCGAGCTCCTATAAAGTAGTTTTTTGATGGT & 40 & 67.4 & 32.4 & \\
\hline
\end{tabular}


might be very common among the strains. Bacterial species of the same family are shown same colored box. Family names and their colors are shown on the right side of the Figures in italics. The right side of the tree contains the genus names [Figure 5]. The phylogenetic tree was based on aligning the 7 gene sequences of (16S rRNA, 23S rRNA, gyrB, pyrH, recA, rpoA and rpoD).

100bp ladder was used as a DNA ladder. Lane 1-3 were PCR products iceA1 gene. M: Ladder (100bp). Image as viewed on Gel Dock.

\section{Agrobacterium-mediated genetic transformation}

A total of 46 independent brinjal plants were regenerated by Agrobacterium transformation [Figure 6]. Colony PCR of Agrobacterium confirmed the positive expression of iceA1. Bands at the size of $519 \mathrm{bp}$ could be seen in the agarose gel. They were further screened for the iceA1 gene expression by PCR and by Sodium Dodecyl Sulphate-Polyacrylamide Gel Electrophoresis (SDS-PAGE). A PCR product of the expected size (519bp) was obtained from the genomic DNA of all the 5 transgenic lines, which advocates the positive expression of ice 11 [Figure 7]. As expected, negative amplification was seen with no band in control samples (independent non-transgenic). No degree of non-specificity was observed, stating the purity of DNA and specificity of primers.

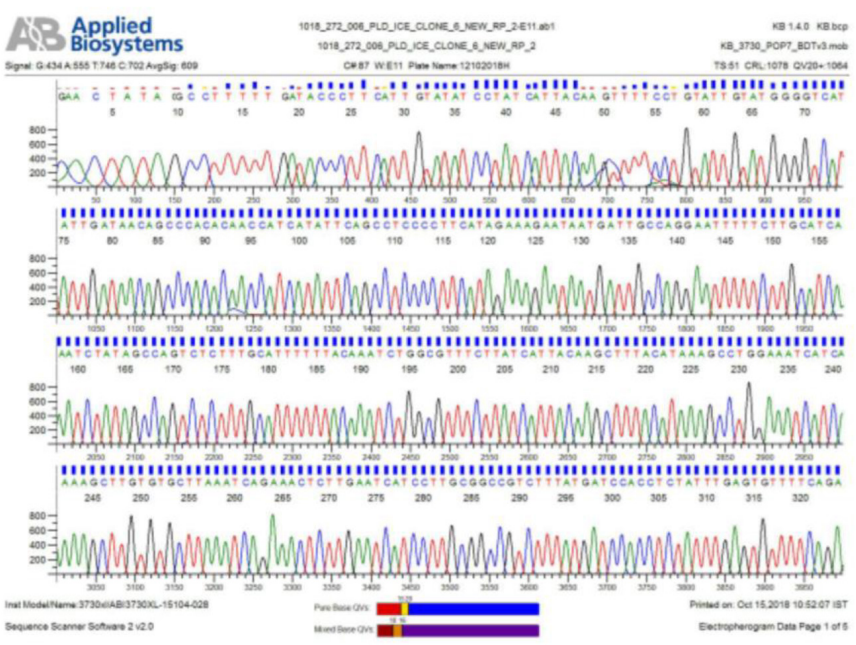

Figure 4: Chromatogram of the released iceA1 gene of insert purified from the gel in the previous section.

Sequencing was done with both forward and reverse primer.

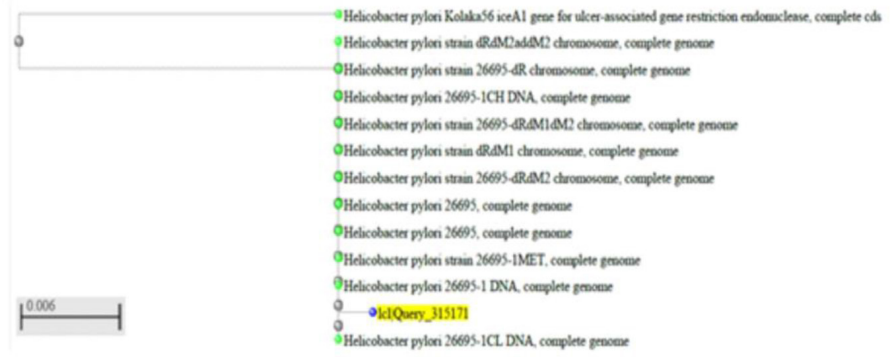

Figure 5: Phylogenetic tree showing the relationship of the nearest family members with the query sequence 315171 .

Our query sequence was iceA1 gene from H.pylori (26695) ATCC 700392.
A

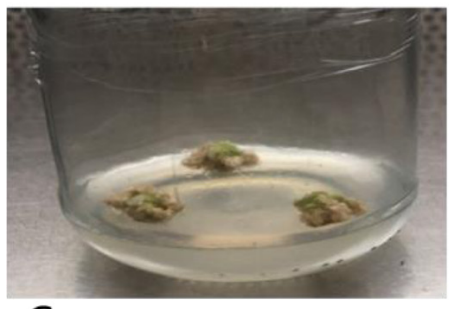

C

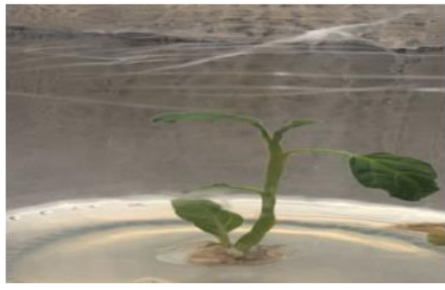

B

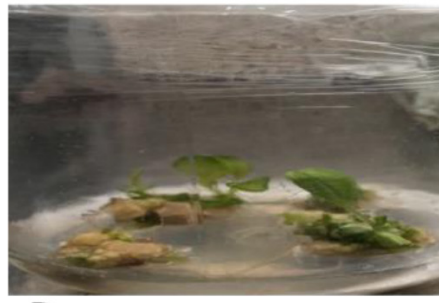

D

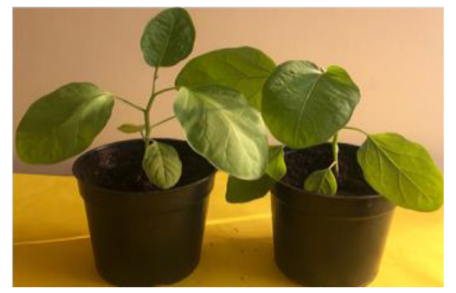

Figure 6: Photographs showing the development of transgenic brinjal cv Arka Keshav following Agrobacterium transformation,

A: Callus initiation, B, C: Regeneration of shoot on selection media, D: growth of plantlets.

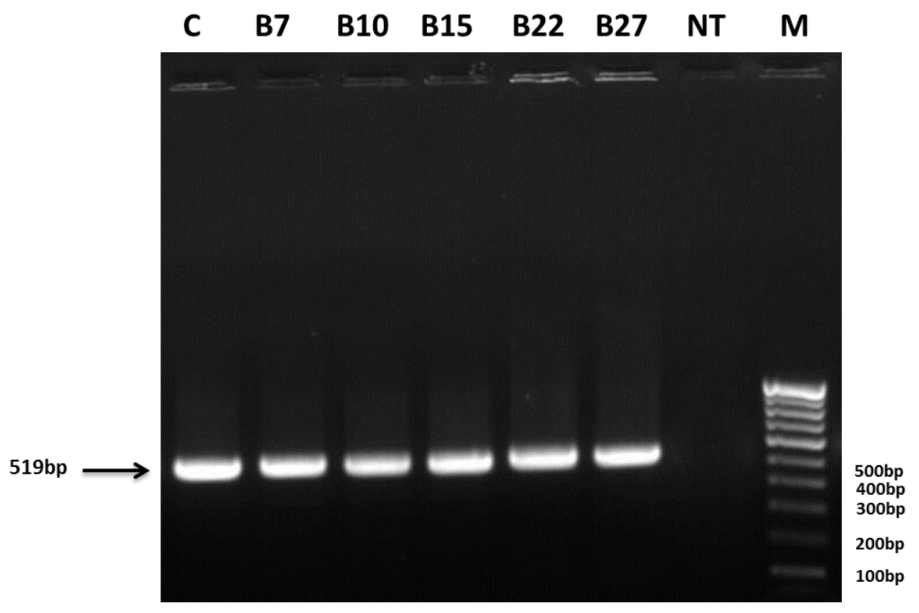

Figure 7: Image showing the PCR amplification of iceA1 gene from gDNA isolated from the leaves of both transgenic and control.

PCR products were run on $1 \%$ agarose gel. $100 \mathrm{bp}$ ladder was used as a molecular marker. Lane NT: Non-transgenic plant; Lane B7, B10, B15, B22 and B27: transgenic plants. Lane 7: Lane C: positive control pBI121-iceA1 positive control

\section{Protein expression}

As seen from the protein electrophoresis, intense bands at about $20 \mathrm{KDa}$ were observed in all the transgenic lines (B7, B10, B15, B22 and B27). No band was seen in case of non transgenic or control line [Figure 8]. This confirms the expression of $i c e A 1$ protein within the leaves of transgenic plants.

\section{DISCUSSION}

Producing therapeutic proteins within plants was reported previously using a wide variety of expression systems, though most of them solved the very purpose partially. ${ }^{42}$ Leaves, vegetables and fruits of plants are used to produce, recombinant therapeutics like vaccines which are cheaper than conventional vaccines. ${ }^{43}$ Helicobacter pylori is one of 


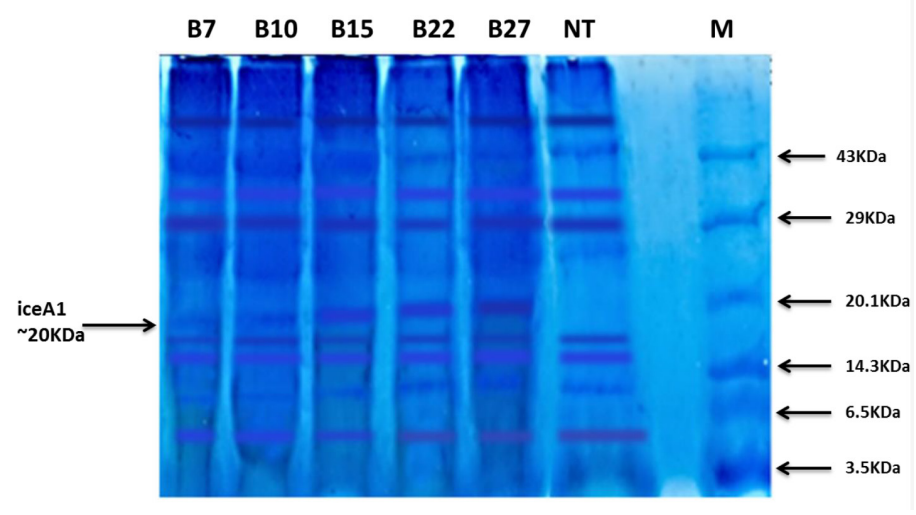

Figure 8: SDS-PAGE gel showing the protein bands of the transgenic and control plants separated.

B7, B10, B15, B22 and B27 are the transgenic plants. NT: Non transgenic. M: Protein ladder. Intense bands were seen at $\sim 20 \mathrm{KDa}$.

the most predominant bacterial strains, which was reported to affect more than $40-50 \%$ of humans worldwide, ${ }^{44}$ causing peptic ulcers and gastric cancer. $H$. pylori, a gram-negative strain colonizes the stomach lining causing chronic gastritis and ulcers, which are prone to develop into adenocarcinoma and lymphoma. ${ }^{45,46}$ Vaccines are inactivated protein suspensions from bacteria or viruses, to elicit the immune response against deadly diseases. ${ }^{2}$ They help the body to detect the foreign antigen through the immune system. In recent decades, plant-based vaccines are being produced in amounts, to not only reduce the harmful effects of traditional vaccines but also to minimize the cost. ${ }^{47,48}$ These genetically altered vaccines from the plants are inserted into plant tissues without even affecting the immunogenicity. ${ }^{49}$

ice $A 1$ antigen gene was cloned into a binary vector pBI121 with selectable marker kanamycin resistance gene and transformed into brinjal callus by Agrobacterium. Out of the 46 plants, five of them were found to be transgenic and was confirmed from the gene amplification studies. The protein expression was also confirmed through SDS-PAGE wherein an intense band of approximately $20 \mathrm{KDa}$ was seen in transgenic lines only. The outputs of our experiments recommend that the iceA 1 transgenic brinjal can further be studied to use as a vaccine candidate against H. pylori.

In the present years, many studies are being done to generate edible vaccines from ready-to-eat fruits and vegetables, to follow the oral route of administration. ${ }^{2}$ Edible vaccines are mostly generated when the desired transgene is inserted into the selected plant cell. In addition, these vaccines are more cheap and safe than other conventional vaccines available in the market. ${ }^{50}$ To conclude, we report the successful integration of the transgene into the nuclear genome of the brinjal plants, with no limitations. These studies of ours confirm that this methodology could be well used to express several valuable proteins. Further we plan to confirm the expression of proteins by quantitative real time PCR and protein expression studies using western blot.

\section{ACKNOWLEDGEMENT}

The authors acknowledge the supports from JSS Research Foundation, JSS Technical Institutions Campus, Mysore; Genei Laboratories Pvt Ltd, Bangalore; Department of Biotechnology and Crop Improvement, Postgraduate Centre, College of Horticulture, University of Horticulture Sciences Campus, GKVK, Bangalore and Postgraduate Department of Biotechnology, JSS College, Mysore.

\section{CONFLICT OF INTEREST}

The authors declare no potential conflicts of interest.

\section{ABBREVIATIONS}

WHO: World Health Organization; MALT: Mucosa Associated Lymphoid Tissue; PCR: Polymerase chain reaction; TE buffer: Tris EDTA buffer; HCl: Hydrochloric acid; BAP: 6-Benzyl Amino Purine; NAA: Naphthalene acetic acid; SDS-PAGE: Sodium Dodecyl Sulphate-Polyacrylamide Gel Electrophoresis.

\section{Author contributions}

MJM, BYSK and RB conceived and designed the study, MJM and RB performed the experiments, MJM, BYSK, NH, RB, BF and SP analyzed the data, MJM and SP drafted the manuscript and all the authors reviewed the manuscript.

\section{Consent for publication}

All authors consent to publish this work.

Ethics approval

IBSC Registration number: JSSC111220191080.

\section{REFERENCES}

1. Mehran MJ, Zendehbad SH, Malla S. Cloning and expression of a partial UreA antigen for the production of vaccine against Helicobacter pylori, the risk factor for gastric cancer. Asian J Pharm Clin Res. 2014;7:111-7.

2. Kurup V M, Thomas J. Edible vaccines: promises and challenges. Mol Biotechnol. 2020;62(2):79-90. doi: 10.1007/s12033-019-00222-1, PMID 31758488.

3. Madanala R, Gupta V, Pandey AK, Srivastava S, Pandey V, Singh PK, Tuli R. Tobacco chloroplasts as bioreactors for the production of recombinant superoxide dismutase in plants, an industrially useful enzyme. Plant mol biol rep. Plant Mol Biol Rep. 2015;33(4):1107-15. doi: 10.1007/s11105-014-0805-2.

4. Kashima K, Yuki Y, Mejima M, Kurokawa S, Suzuki Y, Minakawa S, et al. Good manufacturing practices production of a purification-free oral cholera vaccine expressed in transgenic rice plants. Plant Cell Rep. 2016;35(3):667-79. doi: 10.1007/s00299-015-1911-9, PMID 26661780.

5. Rawla P, Barsouk A. Epidemiology of gastric cancer: global trends, risk factors and prevention. Prz gastroenterol. 2019;14(1):26-38. doi: 10.5114/pg.2018.80001, PMID 30944675

6. Baj J, Forma A, Sitarz M, Portincasa P, Garruti G, Krasowska D, Maciejewski R Helicobacter pylori virulence factors-mechanisms of bacterial pathogenicity in the gastric microenvironment. Cells. 2020;10(1):27. doi: 10.3390/cells10010027, PMID 33375694.

7. Humans, I. W.G.o.t.E.o.C.R.t, cancer.A.f.R.o. and Organization. W.H. 1994 Schistosomes, liver flukes and Helicobacter pylori. International Agency for Research on Cancer.

8. Fallone CA, Chiba N, van Zanten SV, Fischbach L, Gisbert JP, Hunt RH, et al. The Toronto consensus for the treatment of Helicobacter pylori infection in adults. Gastroenterology. 2016;151(1):51-69.e14. doi: 10.1053/j.gastro.2016.04.006, PMID 27102658.

9. Romano M, Ricci V Zarrilli R. Mechanisms of disease: Helicobacter pylorirelated gastric carcinogenesis-implications for chemoprevention. Nat Clin Pract Gastroenterol Hepatol. 2006;3(11):622-32. doi: 10.1038/ncpgasthep0634 PMID 17068500.

10. Pucułek M, Machlowska J, Wierzbicki R, Baj J, Maciejewski R, Sitarz R Helicobacter pylori associated factors in the development of gastric cancer with special reference to the early-onset subtype. Oncotarget. 2018;9(57):31146-62. doi: 10.18632/oncotarget.25757, PMID 30123433.

11. Di Ciaula A, Baj J, Garruti G, Celano G, De Angelis M, Wang HH, et al. Liver steatosis, gut-liver axis, microbiome and environmental factors. A never-ending bidirectional cross-talk. J Clin Med. 2020;9(8):2648. doi: 10.3390/jcm9082648, PMID 32823983.

12. Machlowska J, Baj J, Sitarz M, Maciejewski R, Sitarz R. Gastric cancer: epidemiology, risk factors, classification, genomic characteristics and treatment strategies. Int J Mol Sci. 2020;21(11):4012. doi: 10.3390/ijms21114012, PMID 32512697.

13. Malfertheiner P, Megraud F, O'Morain CA, Gisbert JP, Kuipers EJ, Axon AT, et al. Management of Helicobacter pylori infection-the Maastricht V/Florence Consensus Report. Gut. 2017;66(1):6-30. doi: 10.1136/gutjnl-2016-312288, PMID 27707777.

14. Donahue JP, Peek Jr RM, Van Doorn LJ, Thompson SA, Xu Q, Blaser MJ, et al. 
Analysis of iceA1 transcription in Helicobacter pylori. Helicobacter. 2000;5(1):1-12. doi: 10.1046/j.1523-5378.2000.00008.x, PMID 10672045.

15. Ciftci IH, Uslan I, Dilek FH, Asık G, Ozgür MA, Dilek ON. Investigation of Helicobacter pylori iceA1 and iceA2 genes in patients with chronic gastritis and gastric cancer. Mikrobiyol Bul. 2011;45(2):228-33. PMID 21644065.

16. Nishiya D, Shimoyama T, Fukuda S, Yoshimura T, Tanaka M, Munakata A. Evaluation of the clinical relevance of the iceA1 gene in patients with Helicobacter pylori infection in Japan. Scand J Gastroenterol. 2000;35(1):36-9. doi: 10.1080/003655200750024506, PMID 10672832.

17. Essawi T, Hammoudeh W, Sabri I, Sweidan W, Farraj MA. Determination of Helicobacter pylori virulence genes in gastric biopsies by PCR. ISRN Gastroenterol. 2013;2013:606258. doi: 10.1155/2013/606258, PMID 23691338.

18. Gorrell R, Kwok T. The Helicobacter pylori methylome: roles in gene regulation and virulence. Curr Top Microbiol Immunol. 2017;400:105-27. doi: 10.1007/9783-319-50520-6_5, PMID 28124151.

19. Cheng C, Chen Z, Zhu C. Construction of plant expression vectors with fusion gene of Helicobacter pylori cagA, ureB and ctb and its genetic transformation in tobacco. Wei sheng wu xue bao. 2007;47(1):29-33. PMID 17436619.

20. Sabalza M, Christou P, Capell T. Recombinant plant-derived pharmaceutical proteins: current technical and economic bottlenecks. Biotechnol Lett. 2014;36(12):2367-79. doi: 10.1007/s10529-014-1621-3, PMID 25048244.

21. Abdoli-Nasab M, Jalali-Javaran M, Cusidó RM, Palazón J, Baghizadeh A, Alizadeh $\mathrm{H}$. Expression of the truncated tissue plasminogen activator (K2S) gene in tobacco chloroplast. Mol Biol Rep. 2013;40(10):5749-58. doi: 10.1007/ s11033-013-2678-0, PMID 24114696

22. Shanmugaraj $B$, Ramalingam S. Plant expression platform for the production of recombinant pharmaceutical proteins. Austin. J Biotechnol Bioeng; 1.

23. Soria-Guerra RE, Rosales-Mendoza S, Márquez-Mercado C, López-Revilla R, Castillo-Collazo R, Alpuche-Solís AG. Transgenic tomatoes express an antigenic polypeptide containing epitopes of the diphtheria, pertussis and tetanus exotoxins, encoded by a synthetic gene. Plant Cell Rep. 2007:26(7):961-8. doi: 10.1007/s00299-007-0306-y, PMID 17619922. -. 007-0306-y, PMID 17619922.

24. Bustin SA, Nolan T. Pitfalls of quantitative real-time reverse-transcription polymerase chain reaction. J Biomol Tech. 2004;15(3):155-66. PMID 15331581

25. Gachon C, Mingam A, Charrier B. Real-time PCR: what relevance to plant studies?. J Exp Bot. 2004:55(402):1445-54. doi: 10.1093/jxb/erh181, PMID 15208338

26. Chuaqui RF, Bonner RF, Best CJ, Gillespie JW, Flaig MJ, Hewitt SM, et al. Post-analysis follow-up and validation of microarray experiments. Nat Genet. 2002;32;Suppl:509-14. doi: 10.1038/ng1034, PMID 12454646.

27. Czechowski T, Stitt M, Altmann T, Udvardi MK, Scheible WR. Genome-wide identification and testing of superior reference genes for transcript normalization in Arabidopsis. Plant Physiol. 2005;139(1):5-17. doi: 10.1104/pp.105.063743, PMID 16166256.

28. Streatfield SJ, Howard JA. Plant production systems for vaccines. Expert Rev Vaccines. 2003;2(6):763-75. doi: 10.1586/14760584.2.6.763, PMID 14711360

29. Wei Q, Du L, Wang W, Hu T, Hu H, Wang J, David K, Bao C. Comparative transcriptome analysis in eggplant reveals selection trends during eggplant domestication. Int J Genomics. 2019;2019:7924383. doi: 10.1155/2019/7924383, PMID 31211132

30. Kalloo G. Eggplant: Solanum melongena L. genetic improvement of vegetable crops. 1993; 587-604

31. Meyer RS, Karol KG, Little DP, Nee MH, Litt A. Phylogeographic relationships among Asian eggplants and new perspectives on eggplant domestication. Mol Phylogenet Evol. 2012;63(3):685-701. doi: 10.1016/j.ympev.2012.02.006, PMID 22387533.

32. Hirakawa H, Shirasawa K, Miyatake K, Nunome T, Negoro S, Ohyama A, et al. Draft genome sequence of eggplant (Solanum melongena L.): the representative solanum species indigenous to the old world. DNA Res. 2014;21(6):649-60. doi: 10.1093/dnares/dsu027, PMID 25233906.

33. Mishiba KI, Nishida K, Inoue N, Fujiwara T, Teranishi S, Iwata $Y$, et al. Genetic engineering of eggplant accumulating $\beta$-carotene in fruit. Plant Cell Rep. 2020;39(8):1029-39. doi: 10.1007/s00299-020-02546-8, PMID 32382812.

34. Chang AY, Chau V, Landas JA, Pang Y. Preparation of calcium competent Escherichia coli and heat-shock transformation. JEMI Methods. 2017;1:22-5.

35. Sambrook J, Russell DW. The condensed protocols from molecular cloning: a laboratory manual; 2006.

36. Prakash D, Deepali B, Asokan R, Ramachandra Y, Shetti D, Anand L, Hanur VS Effect of growth regulators on in vitro complete plant regeneration in brinjal. Indian J Hortic. 2013;65:371-6.

37. Patel M, Dewey RE, Qu R. Enhancing Agrobacterium tumefaciens-mediated transformation efficiency of perennial ryegrass and rice using heat and high maltose treatments during bacterial infection. Plant Cell Tiss Organ Cult. 2013;114(1):19-29. doi: 10.1007/s11240-013-0301-7.

38. Li Z, Parris S, Saski CA. A simple plant high-molecular-weight DNA extraction method suitable for single-molecule technologies. Plant Methods. 2020:16:38. doi: 10.1186/s13007-020-00579-4, PMID 32190102.

39. Untergasser A, Cutcutache I, Koressaar T, Ye J, Faircloth BC, Remm M, et al. Primer3-new capabilities and interfaces. Nucleic Acids Res. 2012;40(15):e115doi: 10.1093/nar/gks596, PMID 22730293.

40. Smith CT, Elfstrom CM, Seeb LW, Seeb JE. Use of sequence data from rainbow trout and Atlantic salmon for SNP detection in Pacific salmon. Mol Ecol. 2005;14(13):4193-203. doi: 10.1111/j.1365-294X.2005.02731.x, PMID 16262869.

41. Barzigar R, Haraprasad N, Sathish Kumar BY, Mehran MJ. Cloning and Expression of Vacuolating Cytotoxin A (VacA) Antigenic Protein in Nicotiana benthamiana Leaves a Potential Source of the Vaccine against Helicobacter pylori. Int J Pharm Investig. 2021;11(1):88-93. doi: 10.5530/ijpi.2021.1.16.

42. Furuta $Y$, Namba-Fukuyo $H$, Shibata TF, Nishiyama $T$, Shigenobu $S$, Suzuki $Y$ Sugano S, Hasebe M, Kobayashi I. Methylome diversification through changes in DNA methyltransferase sequence specificity. PLOS Genet. 2014;10(4):e1004272. doi: 10.1371/journal.pgen.1004272, PMID 24722038.

43. Gauntlett JC, Nilsson HO, Fulurija A, Marshall BJ, Benghezal M. Phase-variable restriction/modification systems are required for Helicobacter pylori colonization. Gut Pathog. 2014;6:35. doi: 10.1186/s13099-014-0035-z, PMID 25349630.

44. Nešic D, Buti L, Lu X, Stebbins CE. Structure of the Helicobacter pylori CagA oncoprotein bound to the human tumor suppressor ASPP2. Proc Natl Acad Sci U S A. 2014;111(4):1562-7. doi: 10.1073/pnas.1320631111, PMID 24474782.

45. Lyon F. S on the evaluation of carcinogenic risks to humans IARC monograph. Some Ind Chem. 1994;60:389-433.

46. Furuta Y, Kawai M, Uchiyama I, Kobayashi I. Domain movement within a gene: a novel evolutionary mechanism for protein diversification. PLOS ONE. 2011;6(4):e18819. doi: 10.1371/journal.pone.0018819, PMID 21533192

47. MaY, Lee CJ, Park JS. Strategies for optimizing the production of proteins and peptides with multiple disulfide bonds. Antibiotics (Basel). 2020;9(9):541. doi: 10.3390/antibiotics9090541, PMID 32858882

48. Barzigar R, Haraprasad N, Kumar BYS, Mehran MJ. Challenges and recent developments associated with vaccine antigens production against Helicobacter pylori. Int J App Pharm. 2020:45-50. doi: 10.22159/ijap.2020v12i4.37722.

49. Stern AM, Markel H. The history of vaccines and immunization: familiar patterns, new challenges. Health Aff (Millwood). 2005;24(3):611-21. doi: 10.1377/hlthaff.24.3.611, PMID 15886151.

50. Kalbina I, Engstrand L, Andersson S, Strid A. Expression of Helicobacter pylori TonB protein in transgenic Arabidopsis thaliana: toward production of vaccine antigens in plants. Helicobacter. 2010;15(5):430-7. doi: 10.1111/j.15235378.2010.00786.x, PMID 21083749.

Article History: Submission Date : 25-08-2021; Revised Date : 10-09-2021; Acceptance Date : 10-09-2021.

Cite this article: Mehran MJ, Kumar BYS, Haraprasad N, Barzigar R, Fakrudin B, Paul S. Cloning and Expression of Helicobacter pylori ulcer Associated Gene - iceA1 in Brinjal (Solanum melongena L.). Int. J. Pharm. Investigation. 2021;11(3):338-44. 